\title{
TANTANGAN BANGUNAN ILMU PROFETIK: TEORITIS DAN EMPIRIS
}

\author{
Setyabudi Indartono, Ph.D \\ Email: setyabudi_indartono@uny.ac.id \\ Manajemen FE, UNY, Yogyakarta
}

\begin{abstract}
Islam is believe as a perfect system. It roles all of the aspect of human life. However few scientists are presented to explore a lot of science paradigm based on religion. It is proposed that the progress of science based positivism is theoretically failed. Further scholars suggest that the finding of empirical study of science based positivism is heading a huge of global problem if human life and its environment. Accordingly, this study propose that scholars should investigate and explore various aspect of knowledge and science based on religion or prophetics based.
\end{abstract}

Keywords: prophetics, positivism, empirical finding, theoretical finding

Pendahuluan

Islam adalah sistem yang menyeluruh, yang menyentuh seluruh segi kehidupan. Ia adalah negara dan tanah air, pemerintah dan umat, akahlak dan kekuatan, kasih sayang dan keadilan, peradaban dan undang-undang,ilmu dan peradilan, materi dan kekayaan alam, penghasilan dan kekayaan, jihad dan dakwah, pasukan dan pemikiran, sebagimana juga ia adalah aqidah yang lurus dan ibadah yang benar, tidak kurang dan tidak lebih.

Sebuah kritik yang dilontarkan pada The 2010 World Social Science Report yang dipublis oleh the International Social Science Council (ISSC) Unesco pada tanggal 10 April 2010, mengangkat permasalahan berbagai konsep dan teori ilmu social. Mereka percaya bahwa konsep-konsep ilmu sosial dan teorinya telah mampu mempengaruhi opini publik dan menjadi debat publik. Hal ini dipercaya sebagai indikasi keberhasilan ilmu-ilmu sosial termasuk didalamnya ilmu ekonomi, politik, dan sosiologi.

Namun Social Science Report merilis diantaranya bahwa ilmu ekonomi dinilai tidak mampu untuk mengantisipasi krisis ekonomi dan para ilmuwan politik sering dituduh tidak mampu mengantisipasi krisis ekonomi dengan ilmu mereka, serta Ilmu sosiolog dianggap gagal untuk mengidentifikasi tren sosial ke depan. Ilmu-ilmu sosial telah dituduh terfragmentasi, overspecialized dan kadang-kadang 
terlalu sulit untuk difahami. Ilmu sosial yang telah menjadi begitu menyebar dan meluas dianggap tidak mampu memahami dan membentuk kehidupan sehari-hari menjadi lebih baik. Salah satu saran yang diberikan dalam Social Science Report ini adalah, berbagai temuan dan konsep ilmu social harus secara terus menerus dievaluasi agar memberikan kemanfaatan bagi manusia sebagaimana ilmu ekonomi, sosial, politik dan lainnya. Dan Pengembangan ilmu social harus disinkronkan dengan keyakinan dan agama. Hal ini membuktikan kegagahan perkembangan ilmu yang dimulai akibat revolusi industry mulai runtuh.

\section{Filsafat positivisme}

Filsafat pengetahuan Positivisme (1848/1865) muncul dari sudut pandang sekularisme (1851) yang disebabkan oleh revolusi industri (1750-1850). Revolusi Industri dikenal pada saat perubahan teknologi dan menjadi lebih umum dengan tahun 1830-an. Perubahan teknologi yang menyebabkan revolusi industri mengubah seluruh masyarakat sipil dan memunculkan paradigma intelektual seperti Kapitalisme, Sosialisme dan Romantisisme. Gerakan kapitalisme didukung oleh Étienne Clavier (1788); Arthur Young (1792); David Ricardo (1817), Samuel Taylor
Coleridge, (1823); Pierre-Joseph

Proudhon (1840) ; Benjamin Disraeli (1845); Karl Marx dan Friedrich Engels (1848).

Perkembangan faham sosialisme (1871) adalah sebagai kritik dari gerakan kapitalisme yang dimotori gerakan Marxisme sebagai dasar reaksi atas revolusi industry. Karl Marx berpendapat bahwa industrialisasi menyebabkan masyarakat terbelah menjadi kelompok bourgeoisie (kelompok yang menguasai produksi, pabrik dan lahan) dan kelompok besar yang disebut proletariat (kelompok buruh). Dia menganggap bahwa proses industrialisasi adalah praktek ekonomi feodal dalam mengembangkan faham kapitalisme.Faham sosialis beranggapan bahwa nilai dan tantangan budaya serta praktek ekonomi adalah hasil kreasi sosial.

Gerakan dan faham Romanticism adalah pertentangan antara hasil revolusi industri dan seni. Gerakan ini didukung oleh para seniman puisi separti William Blake dan William Wordsworth, Samuel Taylor Coleridge, John Keats, Lord Byron dan Percy Bysshe Shelley, dan seniman music seperti E.T.A. Hoffmann yang dikenal sebagai Mozart, Haydn dan Beethoven (1810). Gerakan ini menekankan pada pentingnya hal yang alamiah di seni dan bahasa yang 
berlawanan dengan mesin-mesin dan pabrik-pabrik besar.

\section{Sekularisme}

Ketiga faham ini, Kapitalisme, Sosialisme dan Romantisisme mendorong faham sekularisme yang menghasilkan penghapusan undangundang tentang hak-hak istimewa Gereja dan bangsawan. Sekularisme adalah prinsip pemisahan antara lembaga pemerintah dan orang-orang yang diberi mandat untuk mewakili Negara dari lembaga keagamaan. Faham sekuler beranggapwan bahwa agama adalah keyakinan yang tidak rasional, tidak ilmiah, atau tidak masuk akal. Sehingga Karl Marx menyatakan bahwa agama sebagai "candu rakyat".

\section{Kritik Teoritis dan Empiris}

Sementara itu Sebuah laporan World Economic Forum yang tergabung dalam Insight Report Global Risk Report yang dirilis setiap tahun, 2011, 2012, 2013, Mengungkapkan berbagai fenomena permasalahan global yang dihadapi seluruh Negara di dunia ini. World Economic Forum adalah kerjasama dari berbagai elemen seperti Marsh \& McLennan Companies, National University of Singapore, Oxford Martin School, University of Oxford, Swiss Reinsurance Company, Wharton Center for Risk Management,
University of Pennsylvania, dan Zurich Insurance Group. Diantara problem yang ditemukan dalam riset tersebut adalah financial system failure, governmental system failure, climate change yang tergabung dalam beberapa bidang seperti bidang ekonomi, geopolitik, lingkungan, social dan teknologi. Global Risk Report juga memberikan gambaran keterkaitan dan jejaring masing-masing permasalahan global tersebut satu sama lain. Hal ini memberikan bukti bahwa baik secara konsep dan teori dalam social science report dan secara praktek dan efek penerapan teori dalam global risk report membuktikan secara sangat meyakinkan bahwa hasil perkembangan ilmu yang di endorse oleh semangat sekularisme dan faham positivisme, gagal.

\section{Arus Profetik}

Para ilmuan mencoba untuk mengenalkan agama sebagai dasar dasar konseptual bangunan ilmu pengetahuan. Termotivasi oleh Paus Benediktus XVI, Journal of business 2009 menawarkan call paper special issue yang bertema Kepemimpinan Global. B'OR HA'TORAH adalah jurnal internasional bagi kalangan orang Yahudi yang ingin membuktikan hubungan Taurat dengan ilmu pengetahuan, kreativitas seni, keperilakuan, dan berbagai isu-isu sosial. 
International Conference ke-3 18-19 Januari 2010, Brisbane, Australia mendiskusikan teori ekonomi dengan menggunakan perspektif agama Buddha. International conference 09-11 Juli 2012, Queens 'College, University of Cambridge, Inggris, membahas ilmu pengetahuan dan teknologi yang dijelaskan oleh Quran. Kuntowijoyo dalam bukunya "Islam sebagai Ilmu" (2004): Epistemologi, Metodologi, dan etika, mengangkat sudut pandang untuk mengintegrasikan Quran dan Sains.

\section{Kesimpulan dan saran}

Adalah sebuah tanggungjawab bagi semua civitas akademika muslim untuk membuktikan Kemusliman dan ketaqwaannya dalam ranah akademik.

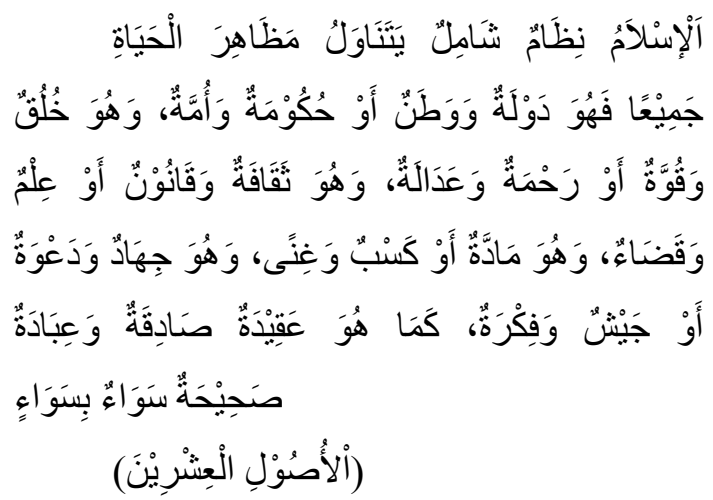

Islam adalah sistem yang menyeluruh, yang menyentuh seluruh segi kehidupan. Ia adalah negara dan tanah air, pemerintah dan umat, akahlak dan kekuatan, kasih sayang dan keadilan, peradaban dan undang-undang,ilmu dan peradilan, materi dan kekayaan alam, penghasilan dan kekayaan, jihad dan dakwah, pasukan dan pemikiran, sebagimana juga ia adalah aqidah yang lurus dan ibadah yang benar, tidak kurang dan tidak lebih (Abu-Faqih, 2007).

Sebuah tuntutan optimalisasi seluruh kemampuan dan kekuatan akademik yang dimiliki kaum muslimin telah diperintahkan Allah dalam surat al Anfal 60 yang artinya "dan siapkanlah untuk menghadapi mereka kekuatan apa saja yang kamu sanggupi dan dari kudakuda yang ditambat untuk berperang (yang dengan persiapan itu) kamu menggentarkan musuh Allah dan musuhmu dan orang orang selain mereka yang kamu tidak mengetahuinya; sedang Allah mengetahuinya. apa saja yang kamu nafkahkan pada jalan Allah niscaya akan dibalasi dengan cukup kepadamu dan kamu tidak akan dianiaya (dirugikan)".

Hal ini sejalan dengan usaha untuk meminimalisir kelemahan yang ada dalam perintah Allah yang artinya: "Janganlah kamu bersikap lemah, dan janganlah (pula) kamu bersedih hati, padahal kamulah orang-orang yang paling tinggi (derajatnya), jika kamu orang-orang yang beriman” (QS. 3:139).

Hal ini diarahkan untuk menangkap peluang untuk maju yang 
harus kita manfaatkan, sebagaimana sudah diindikasikan: "Manusia tidak jemu memohon kebaikan, dan jika mereka ditimpa malapetaka dia menjadi putus asa lagi putus harapan "(QS 41:49). Serta menghadapi berbagai macam tantangan yang ada sebagaimana diarahkan: "Kita adalah orang-orang yang memiliki kekuatan dan (juga) memiliki keberanian yang sangat (dalam peperangan), dan keputusan berada di tanganmu; maka pertimbangkanlah apa yang akan kamu perintahkan “(QS. 27:33).

\section{Bukti Sejarah}

Sejarah cemerlang karya akademik dunia Islam telah tertoreh dengan munculnya berbagai temuan ilmiah oleh para cendekiawan musli. Ibn. Khuldun adalah orang pertama yang merintis ilmu sosial lima abad sebelum renaisance. Pemikiran Ibn. Khuldun selalu mengkaitkan relevansinya dengan al Qur'an dan Hadis sebagai doktrin agama.

Ilmuwan Muslim abad ke 10 yang ahli mathematika, astronomi and fisika: Ibn al-Haitham telah menemukan teknologi Kamera. Seribu tahun sebelum Wright bersaudara, seorang Muslim, penyair, astronomer, musisi dan engineer yang bernama Abbas ibn Firnas telah berusaha membuat konstruksi sebuah mesin terbang di th 852 . Tahun 800 oleh scientist Islam paling terkenal, Jabir ibn Hayyan, mengubah alchemy menjadi chemistry, menemukan banyak proses dasar dan alat-alat yang masih digunakan hingga sekarang seperti alat liquefaction, crystallisation, distillation, purification, oxidisation, evaporation dan filtration. Al-Jazari tahun 1206 menemukan penggunaan katup dan piston, alat jam air mekanik pertama, dan dikenal sebagai bapak robot.

"Kamu adalah umat yang terbaik yang dilahirkan untuk manusia, menyuruh kepada yang makruf, dan mencegah dari yang mungkar, dan beriman kepada Allah. Sekiranya Ahli Kitab beriman, tentulah itu lebih baik bagi mereka; di antara mereka ada yang beriman, dan kebanyakan mereka adalah orang-orang yang fasik." (QS. 3:110).

\section{Referensi:}

ISSC, 2010, World Social Science Report 2010: Knowledge Divides

World Economic Forum, 2016, The Global Risks Report 2016

Al Quran, syamil Quran

Abu-Faqih, Khozin, 2007, Majmu'atur Rasail Hasan Al Banna Kumpulan Risalah Dakwah Hasan Al Banna Jilid-I 